\title{
Local Self-Governing Institutions in India and Fiscal Decentralisation: Issues, Challenges and Policy Prescriptions
}

\author{
Bishnu Prasad Mohapatra \\ Visiting Fellow \\ Research Unit For Livelihoods and Natural Resources (RULNR), Centre For Economic and Social Studies \\ (CESS), Hyderabad
}

\begin{abstract}
The aim of this paper is to analyse the issues and challenges linked with fiscal devolution to the local self governing institutions in India. Local self Governing Institutions in India have been playing a prominent role in implementing development programs. The $73^{\text {rd }}$ amendment act and provisions of Panchayat Act (PESA) have explicitly codified the role of such institutions with regard to implementation of development programs. It is argued that local self-governing institutions on the basis of their time and place knowledge develops plans and programs based on local needs and resources and implements such plans and programs keeping the magnitude of social and political marginalization in mind. Devolution of powers to PRIs in India in last two decades receives widespread importance because of increasing role played by such Institutions in promoting development programs. It is argued that the Local Self-Governing Institutions can become instrumental by promoting development in India, if require inter and intra institutional issues will be taken into consideration. These institutions can perform effectively if needful fiscal, political and administrative powers will be provided within an appropriate institutional framework. However, the issues related to fiscal devolution to local selfgoverning institutions assume significant considering the current development role of PRIs in India.

The present paper critically examines the importance of Fiscal Decentralisation for local self-governing institutions in Indian federation and how the Fiscal Decentralisation agenda for local level governing institutions disturbed because of prevailing institutional and political compulsion. The analysis of this paper is based on secondary source of information. The paper covered three broad aspects i.e. Decentralisation and fiscal decentralisation, fiscal decentralisation to Local Self-Governing Institutions in India and issues as well as challenges for fiscal decentralisation. The paper argues that factors like weak institutional design, absence of appropriate mechanism, problem in federal structure and above all, prevailing political compulsion have disturbed the fiscal devolution agenda of local levels government in India. Seen from the State specific experiences with regard to status of fiscal devolution and recommendation of the State Finance commissions, it is suggested that policies related to the States and local governments' financial relationship need a fresh review. The paper concludes with a broad assumption that local governments should have upper hand in designing development programs and raising revenue in keeping the available local resources in mind.
\end{abstract}

Key Words: Decentralisation, Fiscal Decentralisation, Devolution, Panchayati Raj Institution (PRI), India.

\section{Introduction:}

Local self-governing Institutions in rural India are playing crucial role in implementation of development programs in the current development scenario. These institutions have become instrumental in designing development plans for the rural areas and implement such planed programs in keeping the available fiscal and human resources in mind. The $73^{\text {rd }}$ amendment act of Indian Constitution has widely purveyed a set of legitimate powers to these institutions, with a stately objective to make them as institutions of self-government. The powers and functions codified for these institutions under the purview of Indian Constitution has explicitly pronounced the significance of these institutions with regard to rural development, poverty alleviation and making service delivery effective. However, the current trend of functioning of rural local self-governing institutions in India aptly provides a gloomy scenario because of their failure in tackling critical human development issues. Despite the presence of a progressive governance system like Panchayatiraj, the rural areas in India have faced severe human development challenges. It is argued that the decentralised governing institutions can be able to provide an accountable and transparent administration in the case when certain internal and external conditions will be fulfilled. The conditions like accountability, transparency, participation and fiscal transfers are the key to make the PRIs effective and transparent. However, under the Indian Federal Polity, it is believed that the nature of powers given to the PRIs is residual in nature, often considered as an outcome of political willingness. There are also large scale inter-state disparities in the level of decentralisation in the country (Asfaw et al: 2004) 
The Indian Constitution under its federal character has provided ample provisions for sharing the powers between Centre and States as well as States and local governing institutions (both at rural and urban level). The prominent federal characters include inter alia, division of powers between the Centre and States through three lists i.e. Union list, State list and concurrent list. Centre-State fiscal relations have provided wide array of sharing powers for revenue generation, taxation and expenditure of revenue under the framework of Indian Constitution. Institutionalization of Central Finance Commission is another feature of Centre-State Fiscal Relation. For the purpose of policy making, under Article 246, the subjects of governance are divided into Union, State and concurrent lists. However, the legitimate evolution of local self governing institutions since $1992\left(73^{\text {rd }}\right.$ Amendment) has forced to re-examine the ongoing power-sharing mechanism between the Centre and States in India. It is believed that, the local self-governing institutions in Indian federal polity, enjoying such residual powers which are conferred by the State legislatures. The power sharing exercise between the States and Local levels Government in India provides a dissenting scenario. Especially the fiscal power vested to the Panchayati Raj Institutions (PRIs), often question the issue of rationalization in power devolution arena, thereby provided a platform for academic discussion. Nonetheless, the last two decades of Indian Federal Polity has witnessed extensive Fiscal policy reforms which tend to give a fresh academic overlook on Fiscal devolution to the local governments.

The Local Self-Governing Institutions in India have evolved through a series of historical events, rules, regulations, acts \& commissions and finally reached in a revival stage in the form of $73^{\text {rd }}$ amendment act (1992) \& PESA Act (1996). It is argued that the political and economic theory of decentralisation have evolved over the period of time, which paved the way for institutionalization of decentralised governing institutions in India (Raghunandan: n.d). However, it is argued that the functioning of local self-governing institutions in India, has encountered challenges, which are acute in the form of fiscal in nature. Such challenges hampered the functioning of these institutions. Politicization of local democracy and existence of structural impediments to the effective functioning of local self-governing institutions encourages local elite's dominance in these institutions. Devolution of fiscal powers to the PRIs has provided fruitless result. The issues of fiscal autonomy of these institutions writ large, notwithstanding recommendations of Central \& State finance commissions on that regard. In the absence of transfer of fiscal powers, including powers of raising revenue from local sources, the PRIs dependency on central \& State Governments enhanced. Such situation has hampered the spirit of "selfgoverning institutions" by reducing their functions as "implementing agencies" of government. In the context of changing political scenario, party system and emergence of structural readjustment since 1991, the macroeconomic scenario has been going through a transition phase. Such scenario also paved the way for a fresh analysis of Fiscal Devolution to the PRIs. The present paper is a modest attempt to understand the Fiscal Devolution to PRIs under the present Indian Federal Polity context.

The analysis of this paper reflects two broad realms of functioning of Local Self-Governing Institutions in India. In the First part there is a conceptual discussion about the concept and theory of Decentralisation and Fiscal Decentralisation, Decentralisation in India and broad aspects of fiscal decentralisation. The second part unfolds the current status of fiscal decentralisation to Local Self-Governing Institutions in India and how as well as at what extent the PRIs have faced the issue of fiscal decentralisation in India. The last section provides a set of policy recommendations for enhancing efficacy in fiscal decentralisation to the PRIs in India.

\section{Decentralisation and Fiscal Decentralisation-A Conceptual and Theoretical Framework:}

Over the last two decades many countries around the world have been embarking on the issues of decentralisation. According to Dillinger (1994), out of 75 developing and transitional countries covered in a recent survey, 84 percent have embarked on a certain type of decentralisation process. Asfaw et al (2004) summarizes that decentralisation is a complex and multifaceted concept that involves the shifting of fiscal, political and administrative tasks to lower level governments. Decentralisation as a process of making administration effective which emerged from the ancient period of time in different countries with an ambitious goal to produce better governance. However, scant emphasis was provided for peoples' participation, as the whole concept was based on the theory of "Public Administration". Continuous failure of national \& state governments on pertinent human development issues like poverty \& unemployment with long prevailing centralized administration and deliberate attempt to ignore local needs are believed to be prominent causes of decentralising the governing institutions (Mohapatra:2012).

Assertion in favour of decentralisation is based on its institutional arrangement and capability to address the long standing development issues by devolving power and resources from central or regional authorities to local governments to achieve equity, efficiency and accountability. However Decentralisation also argued by researchers as per their own standpoints which are both political and economic in nature. (Raghunanden: n.d).It is believed that decentralized governance, as an outcome of decentralisation can provide effective and competitive delivery of services at the grassroots level. Being closer to the people, decentralised governance is assumed to meet the needs and preferences of the people. (Crook,2003:77 , Braun \& Grote 
2002:90, Sangitha 2002:145, Breton 2002:41). However, the opponents have a different opinion who argued that decentralisation is a harbinger of macro-economic failure, corruption and monopoly in local governance system (Tanzi: 1995, Prud'homme:1995).

In a country like India, decentralization can be played a prominent role because of vastness in size, population and diversified livelihood system. The decentralized governing institutions are believe to be provided an accountable and transparent administration by nurturing people's participation in implementation of development program. Human development issues like Health, education, sanitation and drinking water, can also be redressed effectively, through effective and vibrant decentralised institutions like PRIs. It is also argued that appropriate power devolution with regards to Fiscal, political \& administrative can enhance effectiveness of Decentralized Institutions.

\section{Fiscal Decentralization: Concept Analysis and Literature Review:}

Over the last few decades, literature on Fiscal Decentralization have flourished both in the theme of political science and economics, mediating between the broad aspects of Decentralised Governance issues and transfers of fiscal powers and authority. The concept of "Fiscal decentralisation" has been extensively discussed in academic and development practitioners circle (Oates, 1972, Bardhan: 2003, Rao: 2000, Marjit, 1999, Oomen, 2004 and 2006, Asfaw et al, 2004, Boex, 2009) and has been attained prominence because of heightened focus given by the different countries in the world while devolving powers and authority to local governing institutions on the issues of finance. The Fiscal Federalism literature which has been evolved during different period of time has provided wide array of theoretical underpinning and empirical evidences on issues pertaining to fiscal transfers to local levels government. The conventional wisdom in the Fiscal Federalism Literature, as narrated by Oates (1972) is based on the notion that decentralisation is to be preferred when the tastes are heterogeneous and there are no spillovers across jurisdiction. With spillovers and no heterogeneity a central government providing a common level of public goods and services for all localities is more efficient , with spillovers decentralisation leads to under provision of local public goods ,as local decision makers do not take into account benefit going to other Districts(Bardhan).The theory of Fiscal Federalism propounded by Oates(1972) negated by researchers, as Bardhan mentioned that "the issue of spillovers is less relevant when the public goods are more local like local roads, minor irrigation, village health clinics and sanitation, identification of beneficiaries of public transfer programs etc. Nonetheless, the arguments on transfer of fiscal powers and resources from the central to local levels governments is linked with idea that "numerous economic benefits arise from shifting public finances closer to the people including a more competitive and innovative public sector, improved allocative efficiency and a more competitive and innovative public sector. There are also robust arguments against large size of governments and in the favour of Cost Effectiveness (Olson, 1965 \& 1971), which believed another endeavor to provide greater fiscal autonomy to local levels governments. According to Olson (1965 \& 1971) in smaller groups, the incentives for free riding would be relatively lesser as free-riders would more easily detect. He also further mentioned that large groups would face relatively high cost when attempting to organize for collective action as compared to local action by small groups.

In Fiscal Federalism literature researchers (Bagchi: 2001, Rao: 2000, Rao and Sen: 2011,Congleton: 2006, Oates: 1972) have attempted to draw a line between early notion of Fiscal Federalism and recent theory of Fiscal Federalism in keeping the rapid economic growth, globalization led development and Decentralisation policy reforms in mind. According to Rao (2011), while the traditional theories called the first generation theories formerly assumed as a benevolent State, the second generation theories draw on the developments in the theory of public choice and industrial organization. The first generation theory is largely based on famous Tiebout (1956) model in which it is argued that when different localities provide varying mixes of public services financed from the tax revenues that they collect from the local population, people will tend to vote with their feet moving and settling with those localities where they perceive that they get the most appropriate mix of services for the taxes they pay. However, Oates believed that decentralised systems were better as voters could exercise their preferences and influence local decisions better through ballot under, which has been conceptualized under "Decentralisation theorem". However, the so called first generation theory has been propounded two significant aspects of fiscal decentralisation i.e. an effective vehicle for better political negotiation \& achieving better delivery of services and a means of achieving spillover externalities of services. In the so called second generation fiscal federal theory, at attempt has been made to defuse the Tiebout(1956) model as well as Oates(1972) idea of decentralisation theorem. The theory of decentralisation in the current period is heavily based on existing political scenario, Institutional arrangements and rapid economic expansion, as well as a source of contestation between State and Market. It is also spelt out widespread failure of MacroEconomy in Latin-America, lack of fiscal discipline, inefficient public spending due to weak local capacity, local corruption and local elite capture. Emergence of new institutions, democratization of polity, advent of a multi-party system, transition from a planed to a market economy (Rao:2003 cited in Litvak,Ahmed and Bird,1998) have paved the way for Fiscal Decentralisation which is based on both political (participation, accountability and transparency) and Economic(Fiscal Transfers, Taxation) aspects of decentralization. 
According to Bardhan, the traditional theory of fiscal federalism now being extended to political economy setting, with the introduction of transaction costs in the political markets, or political agency problems between the ruler and the ruled, between the politicians/bureaucrats and the electorate, and for reasons mentioned above these transaction and agency costs may be much more serious in the context of developing countries.

In the context of India, the Fiscal Decentralisation evolved gradually when there was a strong response came from the academic and development practitioners circle with the flounder of centralized approach of development and economy. The Indian Constitution, with its Federal Character also crated space for vesting fiscal powers and autonomy to Local Levels Government. However, it is argued that, State level variances in the context of fiscal decentralisation in the post- $73^{\text {rd }}$ amendment period, often provided insights to appropriate policy reforms, in keeping the magnitude of poverty, inequality and in equate distribution of public resources. Despite the enactment of $73^{\text {rd }}$ amendment which clearly spelt out fiscal devolutions to PRIs and constitution of State Finance Commissions, the fiscal scenario of PRIs in different States are provided asymmetrical (fiscal devolution) scenario.

\section{Significance of Fiscal Decentralisation for Local Self-Governing Institutions:}

The whole idea of decentralized governance is based upon some key factors like people's participation, accountability, transparency and fiscal transfers (Braun \& Grote, 2002:89; Tanzi 2001:13; Romeo 1999: 137; Crook \& Manor 1998:2; Litvack et. al 1998:7). Fiscal decentralisation, according to Oommen (2008), is an integral subset of decentralisation assumes significance because without its proper functioning decentralisation becomes inoperative and meaningless. Fiscal transfers have an important influence on the effective functioning of democratic decentralised institutions, as it provide impetus to these institutions to work as self-government by vesting autonomy to take time $\&$ prompt decisions regarding the finances of institutions. It is also argued that sound fiscal decentralisation reforms require sound decentralised finances as well as sound decentralised governance and administration. (Boex: 2009). Fiscal autonomy of democratic decentralised institutions has been argued on the ground that "the guarantees for local autonomy lies in the way local governments have at their disposal financial resources which they can autonomously deploy to implement their local level development. Without financial resources any decentralized governance system is empty. Therefore financial resources must cement autonomy (Department of Economic \& Social Affairs, UN). As decentralized governance needs requisite powers for effective functioning \& service delivery, it is believed that transfer of powers can help to decide the allocation and distribution of public resources, the powers to implement policies and programs and the power to raise \& spend public revenues for these \& other purposes. (Johnson: 2003). The Fiscal portfolio of local self-governing institutions is believed to be based upon income from "own revenues" \& "assigned \& devolved revenues" by government \& semi-government organizations (Sahasraman: 2012). It is believed that weak fiscal devolution can make the democratically decentralized institutions handy by creating a culture of "dependency syndrome". However, the opponents of fiscal decentralization argued for limited fiscal devolution, with regard to collection of taxes from local revenues and through managing available resources.

To summarise, Decentralisation in the current development scenario emerged as a key strategy of Government to address the long standing human development issues. Fiscal Decentralisation as an important subset of decentralisation has attained significance, as it is believed that fiscal transfer to local self-governing institutions can produce effective result in addressing the development needs. Nonetheless, the theories of Fiscal Decentralisation has been evolved through different stages and in the context of Globalization and extensive economic policy reforms, in developing and transitional countries, Fiscal Decentralisation Research Arena flourished significantly. In the context of India, the emergence of Third Tier Governments (PRIs) and their Fiscal Issues have provided enough scope to re-look the existing pattern of Fiscal Decentralisation, as it is argued that without Fiscal Devolution, the spirit of Self-Governance may be floundered. In the subsequent section, a humble attempt has been made to unfold the issues relating to the Fiscal devolution to PRIs in India.

\section{Local Self-Governing Institutions and Fiscal Decentralisation in India-A historical Analysis:}

Democratic decentralization in India has a strong historical background, stages of evolution, revival \& growth starting from the ancient Vedic civilization $(1200 \mathrm{BC})$ to modern India. The concept of "self-rule" in the rural India was prevailed during the ancient era in the name of "Sabhas" which were the fertile breeding grounds for taking "participatory community based decisions of self-rule" by the designated traditional village head or a group of heads. The Panchayats had both the executive \& judicial powers, including powers to decide land revenue, village administration \& providing taxes to higher administrative bodies. Mathew (1994) mentioned that the important characteristics of these Panchayats were (during ancient period) that they had been the pivot of administration, the centre of social life, an important economic force and, above all, a focus of social solidarity. 
The British Government's policy towards the stepping of Panchayatiraj Institutions in India, as Institutions of Self-Government was not impressive \& praiseworthy. During this period, administrative and fiscal centralization was a colonial necessity. At the same time the difficulty of administering a large country with a number of principalities, different languages, cultures and traditions did force the Central government to devolve some powers to regional units (Rao:2000). However, it is believed that despite the Centralised administration and Fiscal policy of British Government, several steps were taken by the Government to provide Panchayats to a new shape, through passing acts \& rules in different period of time. Further, till the country's independence, several policy measures were taken by the British Government, including the government of India Acts, 1919 \& 1929, which paved the way for strengthening decentralised Governance in pre-independence India. The Government of India Act, 1935 pronounced the era of federalism by adding the concept of "QuasiFederal" (Rao: 2000)

Local Self-Governance and Fiscal Decentralisation during Post-Independence Period: In the PostIndependent period, the Indian constitution adopted Panchayat Raj system in the part of "directive principle of states policy" as a part to decentralise the administrative powers to the grassroots. However, in the same time the constituent assembly adopted Federal Form of Structure with an intention to make a Strong Centre. Johnson (2003) mentioned that the most enduring image of decentralization in India is Gandhi's vision of Village Swaraj, in which universal education, economic self-sufficiency and village democracy would take the place of caste, untouchability and other forms of rural exploitation. However, it is argued that till 1992, the Panchayatiraj Institutions in India were enjoying no legitimate powers because of Centralised character of Indian Federalism like strong union, centralised planning and programs for Economic Development. According to Rao (2000), formally Indian Federalism was evolved as a two-tier structure until 1992. Nonetheless, local government units existed both in rural and urban areas, which basically acted as agencies of the State Government. Despite the presence of State specific initiatives in the States like Kerala, West Bengal, Karnataka and Odisha, the Panchayati Raj institutions were in a dormant stage till 1992; due to different factors inter alia inadequate powers, poor finances \& lack of political will. The important component of Federalism i.e. Fiscal Federalism which is based on assignment of adequate revenue powers to local levels government was hardly existed in different States.

The $\mathbf{7 3}^{\text {rd }}$ Amendment Act: The $73^{\text {rd }}$ constitution amendment act was a historic enactment which came into force in $24^{\text {th }}$ April 1993 with an objective to provide "constitutional legitimacy" to the Indian Panchayati Raj Institutions. Such initiative provided impetus to the LSGs in India by devolving requisite powers \& functions, which are political and economic in nature. It is argued by the proponent of decentralized governance in India that the $73^{\text {rd }}$ constitution amendment act has ushered a greater degree of uniformity in structure(Three-tier), Composition(reservation for SC,ST \& Women), powers \& functions(financial \& planning), of these institutions with an objective to achieve faster social \& economic development.

The following are the important features of the act which pronounced the greater Fiscal autonomy for PRIs in India;

- Devolution of powers \& Functions including Fiscal Power: Devolution of powers including fiscal powers to PRIs are the most significant aspect that reflected through the $73^{\text {rd }}$ constitution amendment act. It was suggested that the functions of 29 subjects under $11^{\text {th }}$ schedule of Indian Constitution will be devolved to the PRIs for ensuring effectiveness in functional aspects. However the current trend of power devolution to PRIs have provided dismal scenario because of failures of different States in this regard particularly regarding the devolution of fiscal powers.

- Assignment of Revenue powers: The significant component of $73^{\text {rd }}$ amendment is Fiscal powers vested to PRIs. The important component of such process based on collection of tax revenue from local sources, as assigned by the States to these Institutions. According to Oommen(2004) twenty eight types of taxes and rates have been assigned to the local governments since after the enactment of $73^{\text {rd }}$ amendment which are eminently local in character. But still the fiscal autonomy of the PRIs are largely regulated and controlled by the State.

- Plan for Economic Development and Resource Management: Another significant aspect of Fiscal Autonomy is based on preparation of plan for economic development, with keeping the available resources in mind. This has been provided in order to retain the autonomy of Local Self-governing Institutions as selfgovernment, which believed as another assay to provide fiscal autonomy. But the current trend of promoting development program and resource management has become handy, because of existing macro and micro level difficulties.

- Institutionalization of State Finance Commissions (SFCs): The Institutions of State finance commissions were created to examine fiscal relationships between the States \& PRIs as well as Urban Local bodies (ULBs) with regard to collection of tax revenues by the later \& suggests the necessary recommendations thereon. Article 243 (I) \& 243(Y) spelt out the tasks of State Finance Commissions. State level experiences 
shows that the SFCS are become functional with a big question mark about the effective functioning of these institutions in related to rationalizing fiscal relation between states \& local governments. It is argued that the SFCS have missed a great opportunity to contribute to the process of building fiscal federalism (Oommen: 2010) \& the recommendations of SFCs largely ignored which hampered the spirit of selfgovernments (Palharya: 2003).

To summarise, the $73^{\text {rd }}$ amendment to Indian Constitution has aptly provided Fiscal Powers to the Local Self-Governing Institutions to make them more efficient and accountable. The act has also provisioned for the constitution of State Finance Commission (SFCS) in the States to examine the Fiscal Scenario of Local Governments and suggest suitable recommendations to the State to that extent. However, after the two decades of enactment of $73^{\text {rd }}$ amendment, the fiscal positions of PRIs in different States highly disarray and asymmetric in nature. The problems of Fiscal Decentralisation have given two broad pictures i.e. Policy Failure or Failure of State Governments and Failure of the local Governments. These broad issues are analyzed in the subsequent section in order to understand the major gray areas and deduce policy suggestions.

Fiscal Decentralisation and Local Self-Governing Institutions in India: the gray areas: It is argued that Fiscal Decentralization is the Fiscal Empowerment of lower tiers of government which involves the devolution of taxing \& spending powers along with the arrangements for rectifying mismatches in resources \& responsibilities (Oommen: 2006 cited in Fukasaku and De Mellow: 1999; Tanzi: 1996 \& Oommen: 2004). However, the current fiscal power devolution to PRIs in India has been providing two broad areas in which the problems are prevailing.

Policy Failure: Rao (2011) argued that an important feature of a successful system of Fiscal Federalism is the assignment of adequate revenue powers to sub-national governments to forge a strong link between revenue and expenditures at the margin. However, experience from Different States reveals that, the Fiscal Devolution process has more or less confined with the mere delegation of authority without devolving powers of taxation and revenue generation. Failure of States to devolve the desired Fiscal Powers to the Local Level Governments gradually turned these institutions as extended wing of State Governments. Especially in the case of Fiscal Devolution, it has been observed mere Fiscal Delegation have done in different States, without devolving powers, which has been affected the fiscal position of PRIs severely. There is no mechanism devised to assess(mapping) the potential source of revenue of PRIs, therefore no mandatory targets have been set in this regard, which is another policy gap. SFCs recommendations are not taken seriously in the States like Odisha.

Failure of the Local Governments: In the case of India, the $73^{\text {rd }} \& 74^{\text {th }}$ amendments (for urban local bodies) have made the country as largest democratic setup with biggest representative base in the world. There are 2.5 lakhs local governments in India with having 3 million representatives which itself show the vastness of Indian Democratic setup (Oommen: 2010). However, the extent of Fiscal Autonomy enjoying these institutions, in the context of spending and generating revenues, aptly visualize their role in current development scenario. The PRIs in major States in India, have failed to utilize the potential revenue generation source, because of serious capacity gap and over dependency nature. It is also argued that, improving the own revenue is largely linked with two factors major factors i.e. appropriate redesigning of fiscal transfer system and proper institutional arrangements, which are lacking in the case of PRIs.

\section{Challenges:}

Problems in power Devolution: The crucial factor that crippled the fiscal autonomy of PRIs is incomplete in the process of power devolution to the PRIs by different State governments. While in State like Kerala, West Bengal, Karnataka \& Madhya Pradesh has devolved desired powers to the PRIs, in the same time, States like Odisha, Jharkhand have lagged behind the process. Study conducted across Andhra Pradesh, Gujarat, Kerala, Madhya Pradesh, Maharashtra, Tamilnadu, Odisha, Punjab, Haryana, Assam \& Goa also discovered that most states granted a plethora of functional responsibilities but no executive follow-up of granting adequate powers, staff \& additional financial resources was done (Fernandes:2003).

Poor Budgetary allocation: The extent of Fiscal Devolution depends on the expenditure responsibilities and revenue assignments devolved to the lower tiers. However experiences from different States shows that, the fiscal allocations to PRIs declined sharply (Oommen: 2006), which has restricted their development agendas. The total expenditure of local governments(PRIs \& Urban local bodies), as a proportion of the combined expenditure of union, state \& local governments works out to about $6.4 \%$ in $1998-1999$ to $5.1 \%$ in 2002 03.Such indicates the magnitude of Fiscal Poverty of rural Local Self-Governing institutions in India.

Tax Decentralization \& role of State Finance Commissions: In most of the States, the report regarding the recommendations of these commissions not taken into account which is another gray area of fiscal 

decentralization. State experiences on tax decentralization i.e. collection of own tax revenue shows that the local governments own tax revenue has been declined from $5.71 \%$ to $3.97 \%$ in 15 major states in India (Oommen: 2006). It is also argued that, the PRIs should have rights to tax collections from private taxpayers (Marjeet: 1999) which is not reflected in States' tax decentralization agenda.

Fiscal Dependency: The so called Fiscal Decentralization has given the birth of Fiscal Dependency of PRIs over Central \& State hierarchies. Such scenario has lead to Fiscal Inefficiency of PRIs by reducing their role as mere implementer of government programs. For implementation of different programs the PRIs are awaiting "sanction orders" of upper level government departments, which hindered timely \& effective implementation of Development Programs.

Gap in coordination: One of the most important pre-conditions for efficient Fiscal Federalism is clarity in the assignment system. Not only that the assignment system should be clear as far as possible, but when there is overlapping, there should be system and institutions to resolve it (Rao: 2011). However in the case of PRIs Intra $\&$ inter institutional coordination gap is also largely seen in the process of transferring funds to PRIs, which is another challenging area in fiscal decentralization. Flow of funds from higher to lower tiers has become a cumbersome affair because of undue delay, technical incompetency \& high handedness attitude.

Policy prescriptions: The PRIs in India needs a greater degree of political willingness \& effective fiscal devolution for functioning as institution of self government. The following needs to be taken into consideration, in order to make these institutions as self-government.

- It is necessary to assign more powers to PRIs for raising revenues from the local sources i.e. both tax \& non-tax revenue for enhancing their fiscal viability. This urged a fresh analysis of fiscal relationship between the States \& PRIs.

- Fiscal devolution to PRIs should be realistic based on current development needs \& priorities. It should be rationalize on the basis on assigned development programs to PRIs \& extent of fiscal position.

- Financial allocation to PRIs should be based on certain minimum criteria like Developmental Needs of the people \& areas. A clear cut mechanism needs to be devised for determining the Budgetary Allocations for the PRIs.

- PRIs need more orientation regarding Functional Duties \& Fiscal Matters. Revenue generation should not be treated as non-obligatory function of PRIs \& the States finance commissions' recommendation should be taken into consideration.

- The Fiscal Disbursement process should be free from bureaucratic incompetency and political control. The process should be done timely with maintaining utmost transparency.

\section{Conclusion:}

Through this paper a set of recommendations have been suggested which can be seen from the lens of policy angels. The arguments for making PRIs as an institution of self-government with devolving Fiscal Powers may help to enhance the Efficiency of these Institutions.

\section{References}

[1] Asfaw,Abay et all,2004: Modeling the Impact of Fiscal Decentralisation on Health Outcomes: Empirical Evidence from India, Centre For Development Research, ZEF Discussion paper on Development Policy, Bonn

[2] Bardhan,P,n.d: Decentralization of Governance and Development, University of Carlifornia, Berkeley.

[3] Boex, Jamie, 2009: Fiscal Decentralisation and intergovernmental Finance Reforms as an International Development Strategy, IDG Working Paper(2009-06), Urban Institute Centre on International Development and Governance.

[4] Crook, Richard \& James Mannor(2000): Democratic Decentralization, OED Working paper Series-11,The World Bank

[5] Dreeze,J \& A.Sen, 1995, India: Economic Development and Social Opportunity, Delhi, Oxford University Press.

[6] Fernandes, Aureliano, 2003: Aggrandizer Government \& local governance; Economic \& political weekly, July, pp2873-2879

[7] Johnson Craig (2003): Decentralization in India: Poverty, Politics and Panchayati Raj, Overseas Development Institute, London

[8] Marjit, Sugata, 1999: Decentralized financing, governance \& public-private cooperation, Economic \& Political Weekly, May, pp1197-1201.

[9] Mathew, Georege,2000: Status of Panchayati Raj in the States \& Union territories of India(ed.), New Delhi, Institute of Social Sciences in assoc. with Concept..

[10] Mohapatra BP, 2012: Institutions, Democratic Decentralisation and Human Development in India, from Fiscal Constraint to Political Control (under publication).

[11] Olson, 1965 \& 1972: The logic of Collective Action, Public Goods and The Theory of Groups.

[12] Oommen, MA, 2006: Fiscal Decentralization to the sub-state level governments; Economic and political weekly, March pp897903.

[13] Oommen, MA,2010: Have the State Finance Commissions fulfilled their constitutional mandates, Economic \& Political weekly, XLV,(30), July pp39-44.

[14] Oommen,MA, 2008 (ed): Fiscal Decentralisation to Local Governments in India, Cambridge Scholars Publishing, UK.

[15] Palharya, Shakun, 2003: Madhya Pradesh; Decentralized Governance hampered by fiscal constraint; Economic \& Political Weekly, March, pp1025-1028. 
[16] Prud'homme, Remy, 1995: The Dangers of decentralization, the World Bank research observer, 10(2).

[17] Raghunandan,TR, n.d: Second generation theories on fiscal federalism; implications for India's decentralisation model.

[18] Rao, MG, 2000: Fiscal Decentralisation in Indian Federalism, Institute For Social and Economic Change, Bangalore.

[19] Sahasraman, Annd, 2012, Panchayat Finances \& the need for devolutions from the State Government, Economic \& Political Weekly, XLVII (4).

[20] Tanzi Vito,1995: Fiscal Federalism and decentralization: a review of some efficiency and macroeconomic aspects, Annual world bank conference on development economics, 1995

[21] Tiebout, CM, 1956: A pure theory of local expenditures, Journal of Political Economy, Vol.64 (5). 